\title{
REVISTAMARACANAN
}

Artigos

\section{O fotojornalismo em revista: o trabalho do fotógrafo e do editor de fotografia em Veja (1977)}

\author{
Photojournalism in review: the work of photographer \\ and of the photography editor in Veja (1977)
}

\author{
Caio de Carvalho Proença \\ Pontifícia Universidade Católica - Rio Grande do Sul \\ caio.proenca@acad.pucrs.br \\ Charles Monteiro \\ Pontifícia Universidade Católica - Rio Grande do Sul \\ monteiro@pucrs.br
}

\begin{abstract}
Resumo: Este artigo reflete sobre três dimensões da fotografia de imprensa na revista Veja, no ano de 1977: o trabalho do fotógrafo Ricardo Chaves ao cobrir as manifestações estudantis em Porto Alegre; o filtro editorial realizado pelo editor de fotografia Sergio Sade; a narratividade, a diagramação e a apresentação das fotografias nas páginas de Veja. A partir de entrevistas com fotógrafos, com o editor da revista e a interpretação das imagens busca-se compreender o fotojornalismo como o produto de uma cadeia de ações e de escolhas que se materializa nas páginas da publicação. Para tanto, é necessário refletir sobre o conceito de fotojornalismo em sua historicidade, em relação ao contexto de mudanças no fotojornalismo brasileiro na década de 1970, como produto do trabalho não apenas do fotógrafo mas de uma equipe de jornalistas em um veículo de imprensa, configurando um lugar social de produção de sentidos acerca da sociedade brasileira com seus conflitos e suas contradições.
\end{abstract}

Palavras-chave: Fotografia; Fotojornalismo; Veja; Revistas semanais.

Abstract: This paper considers three dimensions of press photography on Veja magazine in 1977: the work of photographer Ricardo Chaves covering student demonstrations in Porto Alegre; the editorial filter performed by the photo editor Sergio Sade; the narrative, the layout and presentation of photographs in the magazine. From interviews with photographers and editor, combined with the interpretation of the images, we describe photojournalism as a result of a sequence of actions and choices taking shape in the pages of the magazine. Accordingly, we consider photojournalism in its historicity, and in particular analyze the changing context during the 1970s and 1980s, in which photojournalistic work becomes a creation not only of a photographer but of a team, a social context providing interpretations about the Brazilian society, its conflicts and contradictions.

Keywords: Photography; Photojournalism; Veja; Weekly magazines.

Artigo recebido para publicação em: Outubro de 2015

Artigo aprovado para publicação em: Novembro de 2015 


\section{A cultura visual no Ocidente}

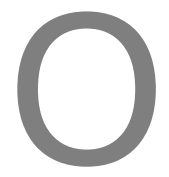

presente artigo ${ }^{1}$ problematiza as imagens produzidas pelo fotógrafo Ricardo Chaves e o trabalho do editor de fotografia Sergio Sade na revista Veja, procurando compreender como se realizou a cobertura fotográfica, a diagramação e a escolha de fotografias sobre as manifestações estudantis em Porto Alegre, em 1977. Procura-se refletir ao respeito do conceito de fotojornalismo em sua historicidade, que deve ser utilizado com cautela pelo historiador. ${ }^{2} \mathrm{O}$ objetivo principal deste trabalho é entender como Veja deu a ver ao leitor as fotografias de Ricardo Chaves acerca das manifestações estudantis de 1977, a partir da edição e da diagramação de Sergio Sade, no contexto das reformas editoriais pelas quais a revista estava passando nos anos 1970. Busca-se, portanto, perceber o fotojornalismo como uma linguagem construída por uma equipe em relação à linha editorial de um veículo de comunicação no contexto de reorganização do fotojornalismo, no Brasil dos anos 1970.

Para isso, compreende-se o termo fotojornalismo como um conceito que abarca diversos atores e práticas fotográficas, realizado não apenas pelo fotógrafo que está na cena do acontecimento mas por um conjunto de profissionais em uma instituição vinculada ao campo da comunicação: diretores de redação, chefes de reportagem, editores de fotografia, redatores, fotógrafos, diagramadores, secretários, arquivistas. O fotojornalismo pode ser compreendido como produto do trabalho dessa equipe de profissionais mas também da ação de outros sujeitos sociais que tencionam este campo da comunicação, como empresários, anunciantes, políticos, censores, etc.

$\mathrm{O}$ artigo está dividido em três partes. Na primeira parte aborda-se o contexto do fotojornalismo no Ocidente e no Brasil nos anos 1970, compreendendo as mudanças ocorridas na área, quais veículos de comunicação estavam surgindo e a influência de outras mídias na fotografia. Na segunda, apresenta-se o formato da revista semanal Veja em 1977, para refletir sobre quem fotografava, escrevia e editava o periódico. Nesse ponto, discute-se o papel do editor de fotografia e seu diálogo com o trabalho dos fotógrafos e jornalistas redatores. Por fim, no terceiro momento, discute-se a cobertura de Veja em torno das manifestações estudantis em Porto Alegre, no ano de 1977. A partir das fotorreportagens, da folha de contatos do fotógrafo Ricardo Chaves e de seus depoimentos, procura-se compreender a

\footnotetext{
${ }^{1} \mathrm{O}$ artigo apresenta resultados parciais do projeto de pesquisa PQ 2 CNPQ "A reorganização do campo e o novo estatuto da fotografia no Brasil nos anos 1970: imagens do fotojornalismo e do fotodocumentarismo", e da pesquisa de mestrado, financiado pelo CNPq, de Caio de Carvalho Proença sobre o fotojornalismo das revistas Veja e IstoÉ nos anos 1976 a 1983, que procura compreender a reorganização do fotojornalismo de revista no contexto das lutas pela abertura política, de reorganização da grande imprensa e de institucionalização da fotografia com a criação do INFOTO.

2 Compreendo que o termo ainda mais completo sobre o fotojornalismo dos anos 1970 é de SOUSA, Jorge Pedro. Uma história crítica do fotojornalismo ocidental. Florianópolis: Letras Contemporâneas, 2004, porém ainda há espaço para uma problematização deste conceito. Proponho dissertar sobre isso como pano de fundo deste artigo, apresentando o conceito como um trabalho conjunto entre fotógrafo, editor de fotografia e diagramação.
} 
construção de significados sociais sobre os acontecimentos pelo fotojornalismo nas páginas da revista Veja.

Este trabalho filia-se à perspectiva teórica de Vilches ${ }^{3}$, Mauad ${ }^{4}$ e Joly ${ }^{5}$ para a interpretação da fotografia na imprensa. Lorenzo Vilches, ao procurar construir uma metodologia de análise da fotografia inserida na página do periódico, auxilia a compreender as diferentes funções que a fotografia possui, tanto no conteúdo quanto em termos de expressão formal (enquadramento, diferentes planos, angulação, foco, contrastes visuais, etc.). $\mathrm{Na}$ mesma direção, Mauad construiu uma proposta metodológica para interpretar a imagem e a construção de significados visuais (conteúdo e expressão) na imprensa. Objetiva-se compreender a narrativa construída na página da revista pelo conjunto de fotografias organizadas em mosaico, observando-se o diálogo entre fotografia e texto (manchete, lead, legenda e créditos). Martine Joly propõe que se interpretem as fotografias em relação a outras imagens do período.

\section{O fotojornalismo ocidental e brasileiro nos anos 1970}

Conforme Sousa, ${ }^{6}$ os anos 1970 foram marcados pela chamada "segunda revolução do fotojornalismo", que se caracterizou pelo jornalismo sensacionalista, pela "espetacularização" e a dramatização de notícias. O trabalho da redação e a atividade do fotógrafo passaram por um processo de rotinização para atender à demanda do mercado da informação. O fotógrafo tornou-se uma espécie de "funcionário" da imagem, que tinha um tempo exíguo para ir a campo em busca de uma imagem que atendesse à premência por novidades dos veículos de comunicação. Naquele momento, as agências internacionais de fotografia se reorganizaram, passando a monopolizar o mercado de fotojornalismo e sua distribuição em escala mundial: Magnum, Gamma, Sygma e Sipa, etc. ${ }^{7}$

Os fotógrafos eram contratados pelos veículos de comunicação ou freelancers que trabalhavam como profissionais autônomos, complementando a equipe e recebendo por tarefa realizada. Isso podia ocorrer na própria cidade ou em outro estado, para a cobertura de um acontecimento que exigisse grande deslocamento e custo alto para ser realizado por fotógrafo da equipe permanente.

Essas fotorreportagens foram realizadas por algumas agências fotográficas que floresceram no final dos anos 1970 e início de 1980 no Brasil. Elas tinham diferentes formas de organização. Algumas eram cooperativas de fotógrafos e outras tinham proprietários que se encarregavam de comercializar as imagens de vários profissionais autônomos. Tendo em vista

\footnotetext{
3 VILCHES, Lorenzo. Teoría de la imagen periodística. 2. impr. Barcelona: Paidós, 1997.

4 MAUAD, Ana Maria. O olhar engajado: fotografia contemporânea e as dimensões políticas da cultura visual. ArtCultura (UFU). v. 10, 2008. p. 31-48.

5 JOLY, Martine. La imagen fija. Buenos Aires: La Marca Editora, 2009.

6 SOUSA, Jorge Pedro. Uma história crítica do fotojornalismo ocidental. Florianópolis: Letras Contemporâneas, 2004. p. 151.

7 MOREL, Gaëlle. Le photoreportage d'auteur. Paris: Editions CNRS, 2006. p. 17-25.
} 
as restrições da liberdade criativa em grandes empresas de comunicação, as agências de fotógrafos eram uma alternativa atraente para vários profissionais com experiências prévias no fotojornalismo, que buscavam uma valorização de seu trabalho, o reconhecimento da autoria das imagens e maior autonomia para criar as suas próprias pautas. Algumas agências como a F4, Ágil fotojornalismo e a Ponto de Vista ${ }^{8}$ procuraram seguir os mesmos princípios de funcionamento das agências fotográficas criadas na Europa e nos EUA após a Segunda Guerra Mundial, especialmente o modelo de Magnum Photo.

Veja e IstoÉ eram as duas revistas semanais de grande circulação mais importantes na década de 1970. Elas possuíam seus próprios staffs de fotógrafos desde que tinham sido criadas em 1968 e 1976, respectivamente, e seguiam os moldes das revistas estadunidenses Time e Newsweek, que serviam de parâmetro editorial para as revistas brasileiras na década de $1970 .{ }^{9}$ A produção fotográfica era guiada por pautas preestabelecidas pela equipe editorial. O fotógrafo recebia uma pauta pré-definida pelo chefe de redação em conjunto com o editor de fotografia. Alguns autores ${ }^{10}$ criticam a posição ocupada pelos fotojornalistas nesses veículos devido à falta de autonomia e sua dependência da empresa jornalística. Porém, existiam diferenças nas relações de trabalho entre os veículos de comunicação. Pode-se questionar ou pelo menos relativizar a falta de autonomia dos fotógrafos na revista Veja no período em foco neste artigo.

O contexto do fotojornalismo nos anos 1970 é percebido por alguns autores como de crise. Jorge Pedro Sousa ${ }^{11}$ compreende que a produção fotográfica nos principais jornais e revistas de grande circulação no ocidente estava caracterizada por fotorreportagens de cunho sensacionalista, que dramatizava os assuntos e explorava a sensibilidade dos leitores, afastando-se assim de sua função primeira, informar.

Por outro lado, André Rouillé ${ }^{12}$ afirma que, desde a década de 1960, o trabalho do fotógrafo de imprensa passou a ser cerceado tanto no âmbito político quanto no institucional. Após a Guerra do Vietnã, a ação dos fotógrafos começou a ser dificultada a fim de controlar a publicação de imagens que iriam contra os interesses dos governos, da indústria bélica e do

\footnotetext{
8 Para mais informações sobre o surgimento das agências fotográficas no Brasil dos anos 1980, procurar a leitura do trabalho de conclusão de curso de Luciano Gomes de Sousa Júnior (2012), que trata especialmente das dificuldades enfrentadas por alguns grupos de fotógrafos, que se uniram com intuito de fugir das "amarras" de empresas de grandes veículos da comunicação, vendendo sua produção mais autônoma para estes mesmos veículos que não trabalhavam mais (como Veja, IstoÉ e jornais em geral).

9 Este será um dos pontos da pesquisa em andamento: perceber quais influências ambas as revistas norte-americanas teriam em Veja e IstoÉ. A partir do que se comentou nas falas de Sergio Sade, Ricardo Chaves, Irmo Celso Vidor e Juca Martins, assim como na produção de BARBOSA, Marialva. História Cultural da Imprensa (Brasil 1900-2000). Rio de Janeiro: Mauad X, 2007, a revista Newsweek fez bastante presença e influenciou redatores, diretores de redação e editores de fotografia de Veja.

10 Para citar apenas alguns, referencio BAEZA, Pepe. Por una funccion crítica de la fotografia de prensa. Barcelona: Editorial Gustavo Gilli, 2001; e RITCHIN, Fred. Bending the frame. Photojournalism, documentary and the citizen. New York: Aperture, 2013.

11 SOUSA, Jorge Pedro. Uma história crítica do fotojornalismo ocidental. Florianópolis: Letras Contemporâneas, 2004.

12 ROUILLÉ, André. A fotografia entre documento e arte contemporânea. São Paulo: Editora Senac São Paulo, 2009. p. 139.
} 
grande capital financeiro. Um exemplo disso foi a ampla cobertura dessa guerra feita por profissionais como Larry Burrows em 1962. ${ }^{13}$

A expansão da televisão também contribui para essa crise da fotografia de imprensa, colocando em xeque a veracidade da fotografia-documento, como afirma Rouillé. ${ }^{14}$ Ela apareceria, nesse contexto, como um forte concorrente da imagem fotográfica estática. Possuía uma linguagem bastante diferente, com imagens em sequência e uma pauta preestabelecida pelas redes de comunicação.

O Vietnã foi muitas vezes vivido pelos repórteres como um corte importante, um ponto de retorno. O fotógrafo era um grande repórter mistificado, adulado, uma espécie de Dom Quixote. [...] $\mathrm{Na}$ arena da atualidade, inverteram-se radicalmente os papéis, os lugares e os meios empregados: "Antes, os fotógrafos ficavam à frente, as emissoras de tevê atrás. Atualmente, são as emissoras de tevê que estão na primeira fileira". ${ }^{15}$

Criava-se uma espécie de teatro visual para o espectador, com uma narrativa muito bem construída por uma equipe, diferentemente da fotografia, que dialogava com o imediato e com o inusitado nesse período, muito embora não dispensasse também sua capacidade teatral em alguns casos.

Em 1954, a televisão a cores surge na rede norte-americana NBC. Poucos anos depois, a japonesa Sony introduz no mercado receptores de televisão por satélite, possibilitando a transmissão de programas ao vivo. Esse cenário modificou o status quo do visual na sociedade ocidental. Para Rouillé:

A televisão impôs sua lei por toda a parte, embora a prática da transmissão direta fosse menos frequente do que hoje em dia (a inauguração dessa função foi o famoso vaivém entre um estudante e um tanque, transmitido de Pequim pela CNN, em 1989, por ocasião da revolta da Praça da Paz Celestial. ${ }^{16}$

Dessa forma, o fotojornalismo começava a tratar da sua produção com mais cuidado e procurava, ainda que não tão forte nesse período, alternativas para manter sua hegemonia perante a capacidade informativa da televisão comparada com a imagem fotográfica; acabara utilizando, como era muito comum no início do fotojornalismo, sequencias de fotografias

\footnotetext{
13 Segundo GOLDEN, Reuel. Photojournalism. 150 years of outstanding press photography. London: Carlton Books, 2011, Burrows tinha completa liberdade para fotografar o teatro da Guerra e suas consequências. Ironicamente, esse acesso foi originalmente garantido porque os militares acreditavam que uma cobertura próxima do acontecimento iriam ajudar o público em sentidos de vender/publicizar a Guerra para pessoas em suas casas. Tradução livre de "Burrows had complete freedom to photograph the theatre of war and its bloody consequences. Ironically, this access was originally granted because the military believed that on-the-spot photographers would help the public relations effort in selling the war to the folks back home".

14 ROUILLÉ, André. A fotografia entre documento e arte contemporânea. São Paulo: Editora Senac São Paulo, 2009, p. 135-159.

15 ROUILLÉ, André. A fotografia entre documento e arte contemporânea. São Paulo: Editora Senac São Paulo, 2009, p. 139.

16 ROUILLÉ, André. A fotografia entre documento e arte contemporânea. São Paulo: Editora Senac São Paulo, 2009, p. 136.
} 
construindo uma narrativa. Fazia sentido, nos anos 1970 e 1980, criar uma história narrada visualmente (uma fotorreportagem) para dar ao leitor algo que ele já estava vendo na televisão: sequencias de imagens e uma linha condutora do argumento visual. Esse tipo de gênero fotográfico foi muito utilizado a partir da década de 1940.

El reportaje es "él género mayor del periodismo", el reportaje es también el género mayor del fotoperiodismo. El desarrollo del reportaje fotoperiodístico es más complejo que ningún otro género. Aborda una historia de interés general que se cuenta en varias imágenes complementarias. A través de sus cuadros, el reportaje gráfico ofrece varios ángulos de una problemática y permite, como otros géneros examinados, que el fotógrafo informe al tempo que vierte su punto de vista. ${ }^{17}$

Durante a segunda metade da década de 1970, no Brasil, publicaram-se diversas revistas semanais de informação. Títulos como Quatro Rodas, Veja, IstoÉ e Placar fizeram grandes publicações a respeito de movimentos políticos e sociais no país. ${ }^{18}$ Nessas revistas, o trabalho do fotógrafo se organizava em dois âmbitos: o fotógrafo contratado (fazendo parte do staff do veículo) e o fotógrafo freelancer (alguns com cargo de freelancer fixo e outros esporádicos, vendendo suas fotografias conforme a necessidade do veículo). ${ }^{19}$ Antes de 1978, as agências fotográficas não estavam praticando ainda sua função política, engajada e social no meio profissional da fotografia como reivindicar direitos de posse dos negativos; requerer a autoria da imagem fotográfica ao fotógrafo; exigir melhorias de condições de pagamento com a criação de diversas tabelas de preços mínimos em cada estado, entre outras características. ${ }^{20}$ Ivan Lima ainda aponta alguns questionamentos sobre o trabalho do fotógrafo durante a década de 1970:

Até essa época [1960] a pauta do jornal levava o fotógrafo a registrar o fato específico com uma foto síntese, que visava apenas à primeira página do jornal. Uma primeira mudança foi conservadora e surgiu com o incremento das agências de jornais, no período pós-1968. Um acontecimento marcante foi 0 surgimento das revistas semanais de

17 CASTELLANOS, Ulises. Manual de fotoperiodismo: retos y soluciones. Ciudad de Mexico: Ed. Universidad Iberoamericana, 2010. p. 37.

18 MARTINS, Ana Luiza; LUCA, Tania Regina de. História da imprensa no Brasil. São Paulo: Editora Contexto, 2012. p. 218-223.

19 MUNTEAL, Oswaldo. GRANDI, Larissa. A imprensa na História do Brasil: fotojornalismo no século XX. Rio de Janeiro: PUC-Rio de Janeiro, 2005.

20 Ver mais em PROENÇA, Caio de C. Fotojornalismo de Ricardo Chaves e Olívio Lamas em Veja: imagens do caso do sequestro clandestino dos uruguaios em Porto Alegre (1978-1980). Trabalho de Conclusão de Curso (Bacharelado em História). Pontifícia Universidade Católica do Rio Grande do Sul, Faculdade de Filosofia e Ciências Humanas, Departamento de História, 82 p., 2014; Ibidem, PROENÇA, Caio de C. In: Revista da Graduação da PUCRS, v. 8, n. 1, 2015; SOUSA JÚNIOR, Luciano Gomes. Fotografia pública nos anos 1980: a nova geração de fotógrafos e a afirmação de uma fotografia brasileira. Trabalho de Conclusão de Curso (Graduação em História). Universidade Federal Fluminense, Instituto de Ciências Humanas e Filosofia, Departamento de História, 2012; SOUSA JÚNIOR, Luciano Gomes. Engajamento político e prática fotográfica no Brasil dos anos 1970 e 1980. Dissertação (Mestrado em História). Universidade Federal Fluminense, Instituto de Ciências Humanas e Filosofia, Programa de Pós-Graduação em História, 140 p., 2014; e MONTEIRO, Charles. El campo de a Fotografía y las imágenes del Brasil en los años 1970-80: Entre el fotoperiodismo y la fotografía documental. In: Artelogie. n. 7, abr. 2015. 
informação com o aparecimento da Veja, em 1968, que segue todos os moldes da revista Time, norte-americana. ${ }^{21}$ (Grifo nosso)

Portanto, o panorama do trabalho fotográfico no Brasil dos anos 1970 ainda estava voltado para periódicos e nichos mais específicos da fotografia em geral (fotografia de produtos, eventos sociais, etc.). No caso, o trabalho do freelancer era bastante visto até meados de 1980. Antes de 1978, quando surgem as primeiras agências de fotografias, o trabalho do fotógrafo de imprensa era visto no âmbito de contratos com jornais e revistas e da venda de fotografias para estes veículos (atuando como freelancer).

A valorização da fotografia em âmbito nacional e internacional assim como a mobilização dos profissionais levaram o governo a criar um órgão público responsável por organizar uma política nacional para a fotografia. ${ }^{22}$ A preocupação desses profissionais era prover a preservação de acervos fotográficos que permitissem refletir sobre a história do Brasil e também estabelecer a fotografia dentro do campo das artes visuais. Para isso, proporiam a organização de exposições, publicação de livros, realização de encontros regionais e seminários nacionais a fim de discutir e implementar políticas públicas para a fotografia. ${ }^{23}$

Quando surgem órgãos do governo federal voltados ao fomento da fotografia, como o Núcleo de Fotografia (1979) e, posteriormente, Instituto Nacional de Fotografia da FUNARTE (1983), a fotografia-expressão, ou fotografia de caráter artístico e documental ganha importância entrando nos museus e nas galerias de arte. ${ }^{24} \mathrm{~A}$ partir da atuação das agências fotográficas, o panorama da fotografia de imprensa também começava a mudar. Fotógrafos começaram a realizar trabalhos de cunho documental em revistas semanais e a publicar fotolivros com ensaios autorais. ${ }^{25}$

\section{A revista Veja em 1977}

Antes da criação do Núcleo de Fotografia da FUNARTE e das agências de fotógrafos no final dos anos 1970, as revistas semanais de informação constituíam-se nos espaços privilegiados de formação, trabalho e legitimação dos fotógrafos profissionais. A revista Veja, no ano de 1977, possuía em média 110 páginas; sua diagramação estava dividida em seções ou grupos editoriais. A capa da revista era uma síntese da reportagem principal - composta por fotografias, ilustrações e fotomontagens. No ano de 1977, as capas começaram a receber

21 LIMA, Ivan. Fotojornalismo brasileiro. Realidade e linguagem. Rio de Janeiro: Fotografia Brasileira, 1989. p. 45.

22 COELHO, Maria Beatriz. O campo da fotografia profissional no Brasil. IN: Varia História, v. 22, n. 35, p. 96, jan-jun, 2006.

23 MONTEIRO, Charles. El campo de a Fotografía y las imágenes del Brasil en los años 1970-80: Entre el fotoperiodismo y la fotografía documental. In: Artelogie. n. 7, abr. 2015.

24 MAGALHÃES, Ângela; PEREGRINO, Nadja Fonseca. Fotografia no Brasil: um olhar das origens ao contemporâneo. Rio de Janeiro: Funarte, 2004.

25 Como é o caso da Agência F4, que publicou diversas fotografias na revista IstoÉ durante os anos de 1979 e 1980, enquanto vários fotógrafos que ali trabalhavam realizaram ensaios de fotografia documental por conta própria. O mesmo ocorreu na agência Ponto de Vista (1979) de Porto Alegre, com o trabalho de fotógrafos como Eneida Serrano, Jacqueline Joner, Genaro Joner e Luiz Abreu. 
maior atenção, tanto pela criação de uma editoria de fotografia quanto pela realização pelo grupo Abril de uma pesquisa com seus assinantes aos moldes das contratadas por revistas como Time e Newsweek.

Essa pesquisa procurou conhecer quais eram as reportagens mais lidas pelos leitores não apenas pelo seu conteúdo e tema mas pela sua diagramação. Com base na pesquisa, soube-se que as reportagens com mais fotografias eram as mais lidas pelos assinantes. As reportagens com fotografias de tamanho médio e grande (ocupando 1/3, 1/2 e até uma página inteira) possuíam uma carga de leitura maior do que as reportagens que continham poucas imagens. ${ }^{26} \mathrm{~A}$ partir dos resultados, criou-se a primeira editoria de fotografia da revista.

Eu já sabia que existia a função de editor de fotografia em algumas revistas internacionais, como a Newsweek, a Time e a Spiegel, que eu acompanhava. Então eu disse para o [Sergio] Pompeu e para o [José Roberto] Guzzo que topava, mas não queria ser "chefe" e sim "editor de fotografia". Como todo o pessoal da redação, eles achavam tratar-se da mesma coisa. Eu insisti que havia uma diferença e apresentei uma proposta: queria participar das reuniões de pauta; queria que toda pauta de texto passasse pela editoria de fotografia, para que eu pudesse pautar o fotógrafo numa linguagem mais técnica e objetiva, de fotógrafo para fotógrafo; queria que as provas contatos viessem do laboratório fotográfico para mim antes de ir para a mesa dos editores, para eu selecionar o material que seria ampliado. ${ }^{27}$ (Grifo nosso)

De qualquer forma, havia ainda um conflito entre o trabalho do fotógrafo e o do jornalista. Até os anos $1950,{ }^{28}$ o cargo do fotógrafo de imprensa era visto como técnico. O jornalista era mais prestigiado e reconhecido como "autor" e, assim, de certa forma, julgavase "dono do fotógrafo". Diante dessa prática assentada, a criação de uma editoria voltada apenas para a fotografia era vista com certa estranheza, fato que acabava criando uma tensão interna na hora da diagramação das fotografias.

Algumas vezes o Pedrinho [Pedro Martinelli] comentava, "puxa, essa foto tem que entrar grande, Sade!", e aí que entra o trabalho do editor. Era uma foto cheia de informação! Não era apenas uma carinha, um boneco. Era o cara fotografado na sua sala, com um monte de informação no segundo plano. Você não pode, quando tem tanta informação assim, cortar só a cara do sujeito. E aí, como já existia a pesquisa de leitura feita pela Abril, que quanto maior e mais informação as fotos possuíssem, mais as pessoas vão se interessar na leitura [...] Então algumas vezes na

26 Ainda há a necessidade de investigar melhor como foi realizada essa pesquisa. Porém, pelos documentos recolhidos do acervo pessoal de Sergio Sade e pelos depoimentos de Sade, Ricardo Chaves e Irmo Celso (trabalho realizado em 2015 por Caio de Carvalho Proença), percebe-se uma unanimidade quanto ao assunto, referindo sempre a esse período como marco para o trabalho dos fotógrafos da revista. Houve, inclusive, uma reunião geral de todos os profissionais da Veja em São Paulo para discutir as mudanças na redação e a fundação da primeira editoria de fotografia - contando assim, a ida de fotógrafos de cada estado do país para São Paulo apenas para perceberem o que mudaria. Foi, para esses profissionais, um acontecimento grande dentro da redação, que nunca havia feito isso antes.

27 Entrevista realizada por Paulo César Boni, publicada na revista Discursos Fotográficos, da UEL. Ver: BONI, Paulo César. Entrevista: Sérgio Sade. In: Discursos Fotográficos, Londrina, v. 7, n. 11, jul./dez. 2011. p. 235-271, p. 241.

28 Ver: LOUZADA, Silvana. Memórias que se espraiam: formação do campo fotojornalístico na modernização da imprensa brasileira. In: Anais VIII Encontro Nacional de História da Mídia, Unicentro, Guarapuava-PR, 2012. p. 1-15. 
diagramação nós falávamos, "aumenta essa foto aí, coloca ela ali, etc.". E o jornalista do texto ali do lado olhando. No fim se fazia um cálculo, "olha, sobraram 450 linhas de espaço para o texto", e o jornalista "não, mas o texto tem 500 linhas"; "é por causa da foto"; "não, corta a foto". Então nós falávamos, a foto não podia ser cortada, algumas nem para ser diminuídas na página. Daí era aquela briga, "não! Corta a foto!", algumas vezes vinha o [José Roberto] Guzzo e confirmava o trabalho, "tira 50 linhas, não vai cortar essa foto não". Cortar uma foto era bem fácil para muitos, agora, tenta tirar 50 linhas de um texto [...] Era um trabalhão para o jornalista reescrever o texto, etc. Por isso que eles ficavam muito bravos. ${ }^{29}$ (Grifo nosso)

Dessa forma, com o apoio de José Roberto Guzzo e Sergio Pompeu (que posteriormente passaria a trabalhar em IstoÉ), o trabalho de Sergio Sade na editoria de fotografia começa a funcionar. Até 1983, essa editoria foi tomando corpo e participando na definição de capas, pautas, diagramação e assuntos fotografados pela equipe de Veja.

A ênfase visual e o espaço da fotografia nas páginas de Veja cresceram ao longo do ano de 1977. Diversas reportagens com fotografias grandes e diagramação em mosaico foram realizadas. O espaço da fotografia pode ser ainda mais facilmente percebido nos anos de 1978 e 1979, quando o chamado Portfolio é criado pela editoria de fotografia. Seria um espaço voltado apenas para a fotografia, compondo uma ou mais páginas da revista somente com fotografias e legendas. Conforme depoimentos de Ricardo Chaves, Irmo Celso e Sergio Sade (em entrevistas realizadas por Caio de Carvalho Proença no ano de 2015), esse seria um espaço para o fotógrafo "mostrar seu trabalho, apresentar ao leitor um conjunto de fotografias suas sobre determinada pauta". A partir dessa prática fotográfica, a equipe criou uma série de fotorreportagens realizadas de maneira conjunta por vários fotógrafos da revista, algo que Sergio Sade aprendera com Darcy Trigo enquanto este era chefe de fotografia da Veja.

Um exemplo da criação desse mosaico de fotografias que abordam um tema central a partir de diferentes ângulos e temáticas individualizadas em cada imagem - produzindo uma narrativa visual - é a fotorreportagem sobre o incêndio do Edifício Joelma em São Paulo (Figura 1). Ela tornou-se um modelo de sucesso que seria repetido diversas vezes por Sergio Sade ao escolher e diagramar as fotografias junto com a equipe de arte de Veja, como nas fotorreportagens sobre a visita de João Paulo II à Polônia, em 1979 (Figura 2).

\footnotetext{
29 Entrevista com Sergio Sade realizada por Caio de Carvalho Proença em 18/05/2015. Transcrição por Caio de Carvalho Proença - acervo do LPHIS/PPGH/PUCRS.
} 

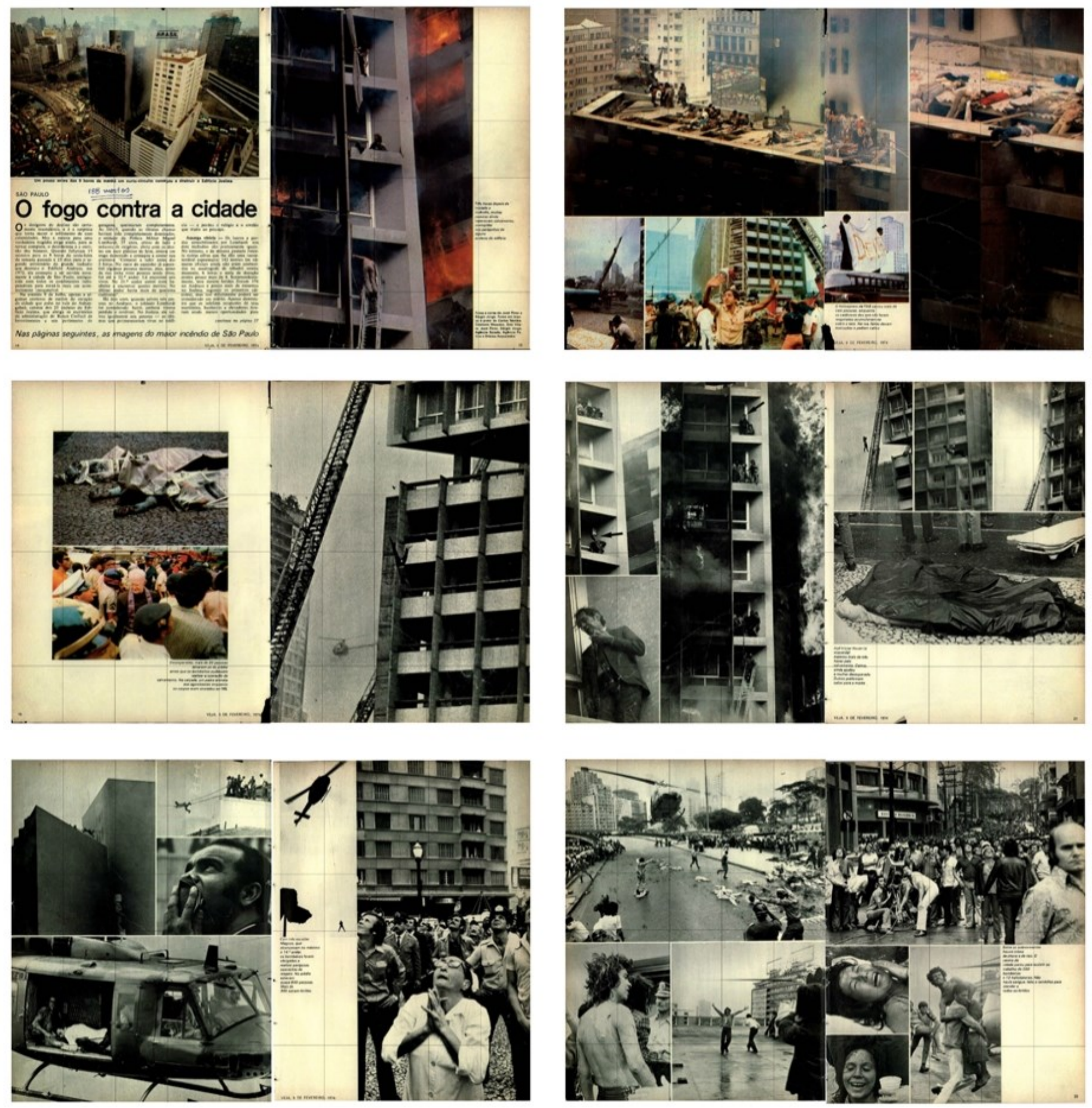

Figura 1: Portfolio de 12 páginas e 26 fotografias feito pela equipe de arte de Veja, a partir das fotografias de Sergio Jorge, José Pinto, Carlos Namba, Cristiano Mascaro, Ezio Vitale, Agência Estado, Agência Folhas e Diários Associados. Edição de fotografia de Darcy Trigo.

Fonte: Veja, 6/02/1974.

Veja possuía, nesse ano, um staff bastante consolidado de fotógrafos. Eram nomes como Walter Firmo, Luiz Humberto, Carlos Namba, Irmo Celso Vidor, Sergio Sade, Marcos Santilli, Ricardo Chaves, Amilton Vieira e Pedro Martinelli, além de outros profissionais, que fotografavam para a revista como colaboradores. Nesse período, Veja não procurava comprar 
de forma habitual fotografias de freelancers, mas utilizar sua equipe de fotógrafos colaboradores em pautas regionais, alocando seu staff por estados. Assim, a maioria das fotografias das pautas nacionais era feita pelo próprio grupo de Veja. Quanto aos assuntos internacionais, a revista contava com serviço de assinatura de imagens de agências como UPI, Associeted Press, Paris Match, Latin-Reuters e France Press.

A revista Veja sustentava um sistema standard de distribuição das editorias entre as 110 páginas em média por edição. Nas páginas iniciais, predominavam propagandas endereçadas ao leitor urbano de classe média, moderno e cosmopolita. Anunciavam-se carros novos, ternos, sapatos, marcas de cigarro, uísque e roupas femininas. Logo a seguir, uma agenda da semana com as opções de entretenimento nas principais cidades do Brasil (algumas vezes a seção era deslocada para o fim da revista) e duas páginas em cores para Milton Viola Fernandes, mais conhecido como Millôr Fernandes - quadrinista, cartunista e jornalista -, que fazia críticas ácidas à política e ao cotidiano do brasileiro.

No miolo da revista, ${ }^{30}$ encontravam-se os principais temas de política e economia nacionais e internacionais. Os temas de política estavam distribuídos entre as seções "Brasil", "Economia \& Negócios" e "Educação". Nessas seções, a fotografia era utilizada. Pode-se afirmar que as maiores pautas foram publicadas nessas três editorias. Ao lado dessas, estava a editoria "Internacional", que publicava fotos de agências estrangeiras ou de fotógrafos da revista enviados ao exterior. Podem-se citar os exemplos de Ricardo Chaves e Pedro Martinelli na cobertura da visita do Papa João Paulo II à Polônia, em 1979 (Figura 2), e de Martinelli que cobriu a Revolução da Nicarágua também em 1979.

O uso da fotografia nessas seções tinha um estatuto de objetividade e de verdade, conforme a deontologia do campo da comunicação ${ }^{31}$ de informar e testemunhar os acontecimentos, de acordo com o paradigma do jornalismo investigativo estadunidense - que teria se iniciado com o caso Watergate nos Estados Unidos ${ }^{32}$ - adotado no Brasil a partir dos anos 1960-70.

\footnotetext{
30 Para conhecer um pouco mais sobre o formato da revista, ver PROENÇA, Caio de C. Fotojornalismo de Ricardo Chaves e Olívio Lamas em Veja: imagens do caso do sequestro clandestino dos uruguaios em Porto Alegre (1978 - 1980). In: Revista da Graduação da PUCRS, v.8, n.1, 2015, p. 46-48.

31 TRAQUINA, Nelson. (Org.). Jornalismo: Questões, Teorias e "Estórias". Lisboa: Vega, 1999.

32 SOUSA, Jorge Pedro. Uma história crítica do fotojornalismo ocidental.Chapecó: Argos Editora Universitária; Florianópolis: Letras Contemporâneas, p. 154-164, 2004.
} 

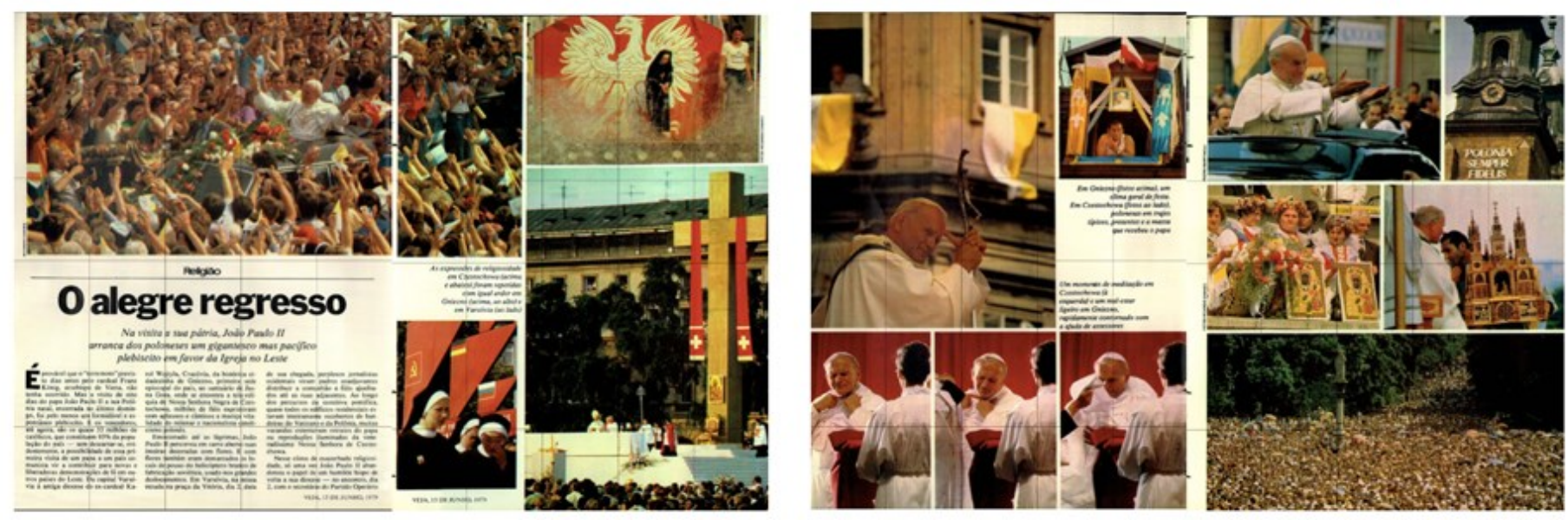

Figura 2: Portfolio de 4 páginas e 14 fotografias coloridas feito pela equipe de arte de Veja, com editoria de Sergio Sade e fotografias de Pedro Martinelli e Ricardo Chaves. Cobertura da visita de João Paulo II à Polônia, em 1979.

Fonte: Veja, 25/07/1979.

Veja fez uso de diversos atributos da linguagem fotográfica de imprensa nas fotorreportagens. Segundo Vilches, ${ }^{33}$ uma fotografia pode construir diversos significados sociais e políticos através de sua edição e diagramação na página do periódico. Entre os diversos exemplos de procedimentos de edição/diagramação da fotografia de imprensa analisados por Vilches, um deles foi bastante utilizado por Veja na construção da visualidade da sociedade brasileira no período dos governos militares, nos anos 1970, tanto na cobertura de assuntos nacionais quanto de internacionais.

\begin{abstract}
Algumas pesquisas demonstraram, por exemplo, que quando existe mais de uma pessoa no campo visual, quem se encontra na esquerda produz maior identificação no observador, enquanto o sujeito à direita é percebido como seu adversário. [...] O valor ideológico de uma fotografia de imprensa nasce por que se atribuem determinados significados para as condições perceptivas dos elementos que se combinam na sua superfície formal. $^{34}$
\end{abstract}

Tal procedimento era frequentemente utilizado nas fotorreportagens de Veja. O uso da imagem a favor do posicionamento editorial, gerando tensões entre olhares, apenas a partir da diagramação e do posicionamento das imagens, pode ser observado na fotorreportagem sobre as relações entre o Brasil no governo de Ernesto Geisel e os Estados Unidos no de Jimmy Carter. O leitor era conhecedor das disputas e das tensões no âmbito das relações

\footnotetext{
33 VILCHES, Lorenzo. Teoría de la imagen periodística. Barcelona: Paidós Comunicación,1997, p.20.

34 Tradução livre de VILCHES (1997), "Algunas investigaciones, por ejemplo, han demostrado que cuando existe más de una persona en el campo visual, quien se encuentra en la izquierda produce mayor identificación en el observador mientras que el sujeto de la derecha viene percibido como un adversario del anterior. [...] El valor ideológico de una foto de prensa nace porque se le atribuyen determinados significados a las condiciones perceptivas de los elementos que se combinan en su superficie formal".
} 
internacionais entre os governos norte-americano e brasileiro. A fotografia do presidente Geisel no lado esquerdo é apresentada em oposição à de Carter no lado direito. O olhar fixo e austero de Geisel na fotografia de N. M. Passos parece dirigir-se ao presidente Carter, à direita, que olha na direção oposta (Figura 3).

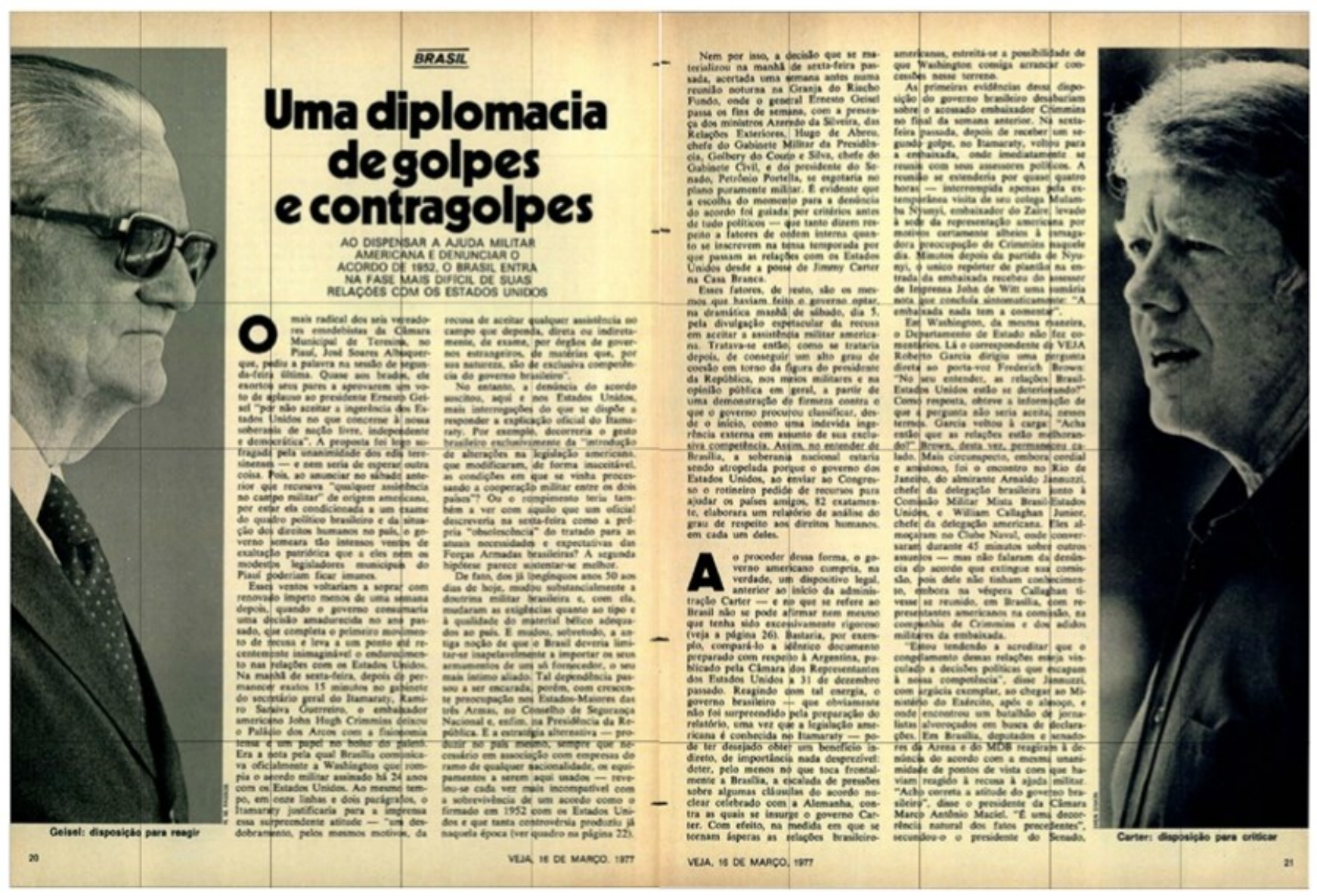

Figura 3: A expressão fotográfica distribuída pelo espaço da página, gerando contrastes de olhares e interesses nas relações internacionais de Geisel e Carter em 1977.

Fonte: Veja, 16/03/1977.

Apesar das seleções e dos cortes na imagem original, dos reenquadramentos e da edição das imagens na página visando a produzir um maior efeito dramático nas fotorreportagens, a equipe editorial da revista Veja atribuía à fotografia um estatuto de documento, num período em que esta estava sendo frontalmente questionada e estava se afirmando a "fotografia-expressão". ${ }^{35}$

A objetividade da fotografia e a tentativa de apresentar ao leitor o real estavam sendo questionadas, conforme aponta Barbosa. ${ }^{36}$ Podem-se perceber os Portfolios de Sergio Sade como certa forma de resistência visual frente às tensões que a fotografia de imprensa vivia

35 ROUILLÉ, André. A fotografia entre documento e arte contemporânea. São Paulo: Editora Senac, 2009.

36 BARBOSA, Marialva. História Cultural da Imprensa (Brasil 1900-2000). Rio de Janeiro: Mauad X, 2007. 
naquele período, tanto pela concorrência da televisão quanto pela crise do estatuto da "fotografia-documento". ${ }^{37}$ A fotografia em Veja aferrava-se ao realismo fotográfico na busca da verdade e da objetividade jornalística. ${ }^{38}$

\title{
A manifestação estudantil em Porto Alegre pelos olhos de Ricardo Chaves
}

Na edição comemorativa de dez anos de Veja no início de 1978, o ano de 1977 seria lembrado em retrospectiva, como repleto de acontecimentos marcantes para o Brasil, em um texto sem autoria, portanto, expressando a opinião da equipe editorial:

\begin{abstract}
As manifestações de rua voltaram, a sucessão presidencial se delineou, os brasileiros ganharam a possibilidade de se divorciar, ministros foram exonerados, anunciou-se o fim do Ato Institucional no 5 - foi um ano, enfim, rico como poucos, nos últimos tempos brasileiros. [...] Em todos os acontecimentos mais importantes de 1977, em suma, de algum modo se lembrou o compromisso de um retorno aos caminhos da democracia. ${ }^{39}$
\end{abstract}

As edições da revista de 1977 publicaram uma série de reportagens sobre as manifestações estudantis nas principais cidades do país. Ricardo Chaves fez a cobertura das manifestações de estudantes da UFRGS e de outras instituições no centro de Porto Alegre, em agosto de 1977. Veja apresentava tais manifestações sem fazer uma crítica direta aos manifestantes, nem as suas ideologias e aos seus atos. Fez uma cobertura textual que apontava vandalismo, atos de repressão e ações da Polícia Militar em todos os estados onde haviam acontecido manifestações estudantis. Ao lado dessas fotorreportagens, desde 1976, Veja vinha publicando uma série de reportagens sensacionalistas sobre política, repressão e lutas pela volta da democracia.

Ricardo Chaves era filho de Hamilton Chaves, que fora jornalista e assessor de imprensa de Leonel Brizola durante o Movimento da Legalidade. Após fazer um curso técnico, começa a realizar seus trabalhos como freelancer. Trabalhou para vários veículos de comunicação do Rio Grande do Sul. Foi fotógrafo na Agência Focontexto e no Coojornal, até ser contratado pela sucursal do Jornal do Brasil e, posteriormente, pela revista Veja, em 1976.

Chaves cobriu as manifestações estudantis de agosto de 1977 em Porto Alegre, com apoio do editor de fotografia Sergio Sade (Figura 4). Utilizando uma máquina Nikon F2, com lente Nikkor $135 \mathrm{~mm}$ e um filme Kodak Tri-X 400 sob forte chuva, ele procurou construir uma história em imagens sobre as manifestações. Na qualidade de fotógrafo, o seu trabalho era dar sentido visual à pauta. Era realizar um ensaio fotográfico ou conseguir uma imagem síntese das manifestações, o que Vilches ${ }^{40}$ chamaria de "imagem periodística", ou seja, aquela que

37 Dando margem a uma interpretação, a partir do que afirma ROUILLÉ, André. A fotografia entre documento e arte contemporânea. São Paulo: Editora Senac, 2009. p. 235.

38 Ver: BECKER, Howard S. Visual sociology, documentary photography, and photojournalism: It's (almost) all a matter of context. Visual Studies, 10, 1995.

39 Veja, 4 de janeiro de 1978, p.36

40 VILCHES, Lorenzo. Teoría de la imagen periodística. Barcelona: Paidós Comunicación,1997. 
propicia um diálogo entre os seus diversos planos focais - tanto o diálogo de primeiro plano quanto o de segundo.

O uso da lente teleobjetiva facilitou o trabalho de Chaves em momentos como aqueles, em que a Brigada Militar fez uso de bombas de gás lacrimogêneo, como se pode observar na fotografia publicada na edição de 31 de agosto de 1977. O uso desse tipo de lente é observado por Ivan Lima:

A teleobjetiva, pelo seu campo visual reduzido, exige recortes extremamente bem feitos, foco apurado, composição rigorosa de linhas verticais e horizontais e pés firmes, condições difíceis de se obter quando se está em pleno fogo dos acontecimentos. ${ }^{41}$

Uma fotografia feita a certa distância do centro focal da imagem, mas que ainda assim mantém no mesmo frame dois planos bem definidos no fotograma de pose 6, 6A, revela: em primeiro plano, os militares avançando enquanto, em segundo plano, os manifestantes correm em sentido oposto; uma manifestante segura a bandeira do Brasil nas mãos e grita em protesto contra o uso do gás lacrimogêneo; outra jovem procura afastá-la enquanto, em primeiro plano, um policial avança em direção às duas.

Essa fotografia foi cortada pelo editor de fotografia Sergio Sade, quando editou as imagens na sede da revista, em São Paulo. Um terço da imagem foi cortado, reenquadrando a cena para dar ainda mais dramaticidade ao acontecimento: o avanço da polícia sobre os estudantes (Figura 5). Com sua caneta vermelha, Sade modifica a fotografia de Chaves em prol do que considera ser informação central na fotografia.

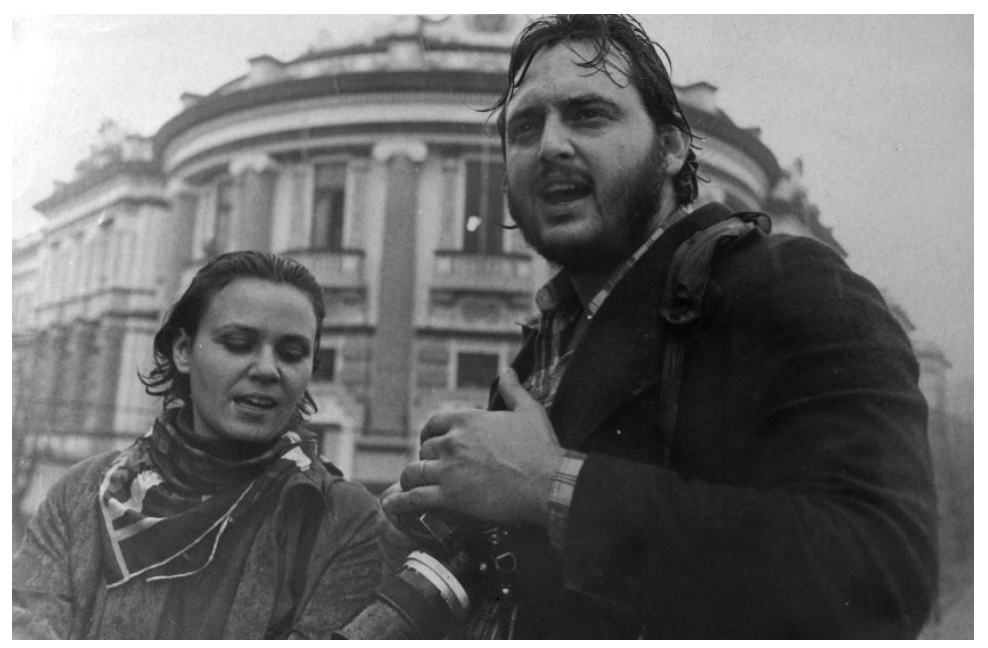

Figura 4: Retrato de Ricardo Chaves no dia das Manifestações, com sua Nikon F2, sob o viaduto na Av. João Pessoa.

Fonte: Acervo pessoal do fotógrafo.

41 LIMA, Ivan. Fotojornalismo brasileiro. Realidade e linguagem. Rio de Janeiro: Fotografia Brasileira, 1989. 


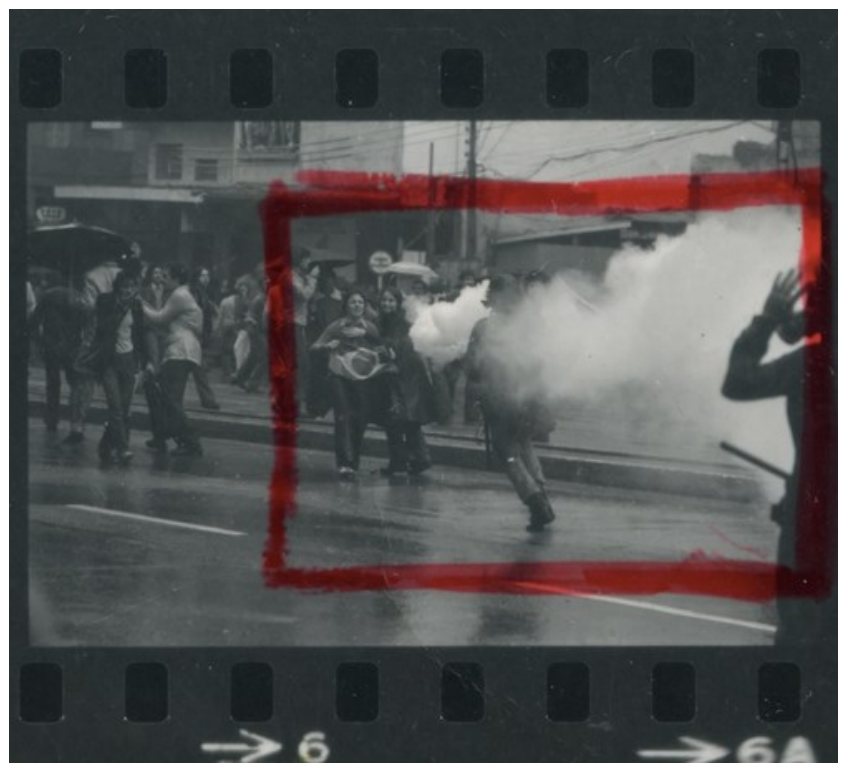

Figura 5: Fotograma de pose $6,6^{A}$ da folha de contatos de Ricardo Chaves com a marca do recorte do editor de fotografia Sergio Sade.

Fonte: Acervo pessoal do fotógrafo.

De acordo com a imagem, no primeiro momento, Chaves enquadra com sua Nikon apenas um aspecto da manifestação: a repressão; Sade realiza um segundo enquadre na fotografia ao retirar a parte esquerda da imagem. Os diagramadores da revista enquadraram essa imagem editada por Sade ao lado de fotografias de manifestações em São Paulo e Salvador.

Já a fotografia de Martinelli do rosto de um homem gritando, individualiza a manifestação de São Paulo, enquanto uma segunda fotografia flagra o momento exato em que um policial militar utilizava seu cassetete para reprimir os estudantes. Na mesma fotografia, observa-se, em segundo plano, uma massa de manifestantes que corre da ação repressiva da polícia (Figura 6). Nessa reportagem, apresentam-se algumas informações sobre as manifestações em Porto Alegre:

No campus da Universidade Federal do Rio Grande do Sul, 1.500 alunos foram cercados pelos quase 700 soldados da Brigada Militar, que não dispensaram de seu aparato bélico sequer as potentes espingardas calibre 12 , de cano serrado [...] À 1 hora da tarde, quando os manifestantes ocuparam as duas pistas da avenida João Pessoa, em frente ao campus, começaram os jatos de água, as correrias, as prisões. Foram cinco horas de agitação, com resultado que não se registrava desde os tumultuados dias de 1968: 32 prisões, dezenas de feridos. ${ }^{42}$

Ricardo Chaves tirou uma série de fotografias das manifestações, como foi possível

\footnotetext{
42 Veja, 31 de agosto de 1977, p.28.
} 
observar na folha contato conservada pelo fotógrafo. Porém, apenas uma foto foi selecionada pelo editor de fotografia para dar a ver as manifestações estudantis no Brasil, naquela edição da revista. O fotojornalismo é, portanto, um trabalho de construção e de produção de sentido em equipe a partir de imagens fotográficas. A imagem produzida pelo fotógrafo foi selecionada pelo editor de fotografia em conjunto com o editor-chefe da revista, depois foi retrabalhada pelo diagramador de página, que procedeu ao recorte e ao reenquadramento dela, finalmente sendo recontextualizada pelo redator sob uma manchete e uma legenda ao lado de um texto. No caso da fotorreportagem das manifestações estudantis de agosto de 1977, a fotografia de Ricardo Chaves recebeu o maior destaque na página dupla. Seguindo uma diagramação clássica de Veja, a fotorreportagem se iniciou com uma imagem de grande formato no topo da página antes da manchete, da legenda e do texto.

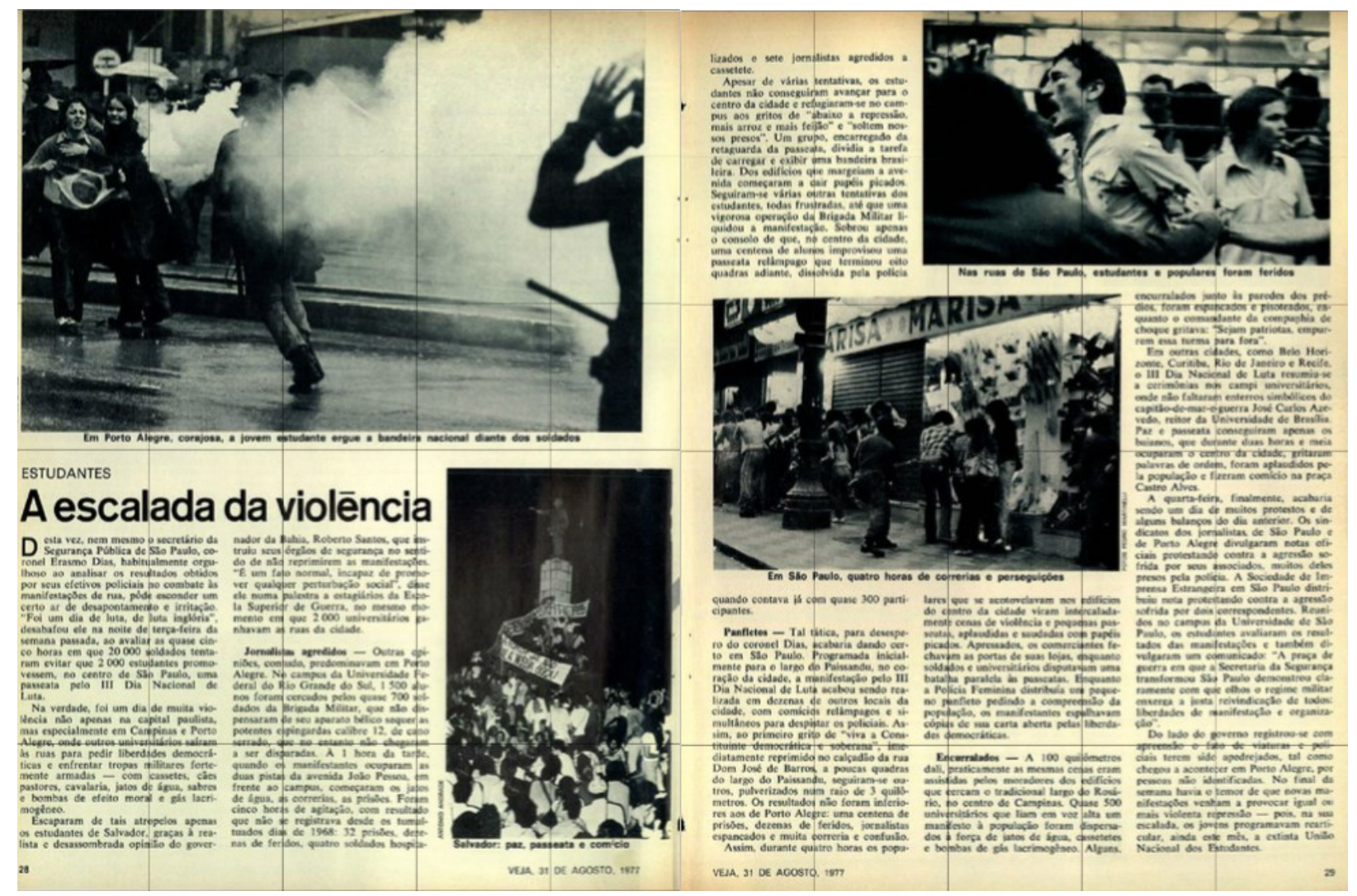

Figura 6: Fotografias sobre as manifestações estudantis no Brasil.

Fonte: Veja, 31/08/1977.

A ação do editor de fotografia coloca em relevo uma das principais reivindicações dos fotógrafos no início da década de 1980: a posse de seus negativos. A posse física e também a ingerência sobre o contexto de utilização das imagens, evitando cortes de fotos.

$\mathrm{Na}$ folha de contato das fotografias de Chaves, o editor escreve uma nota sobre a impossibilidade de manter a narrativa fotográfica que o fotógrafo havia produzido na cobertura 
das manifestações estudantis. Essa folha foi enviada para o fotógrafo com o bilhete escrito a caneta por Sade: "Lutei para dar sequência, mas o espaço [do texto] mais uma vez venceu..." (grifo meu, ver figura 7). A folha de contatos do fotógrafo se afigura como uma fonte importante para compreender as diferentes funções sociais do fotógrafo e do editor de fotografia frente às imposições da editoria de texto e da linha editorial da própria revista. Conforme mencionado por Sergio Sade em seu depoimento, esse tipo de ação se tornaria frequente ao longo da década de 1980, levando a mudanças internas na edição de fotografia de Veja.

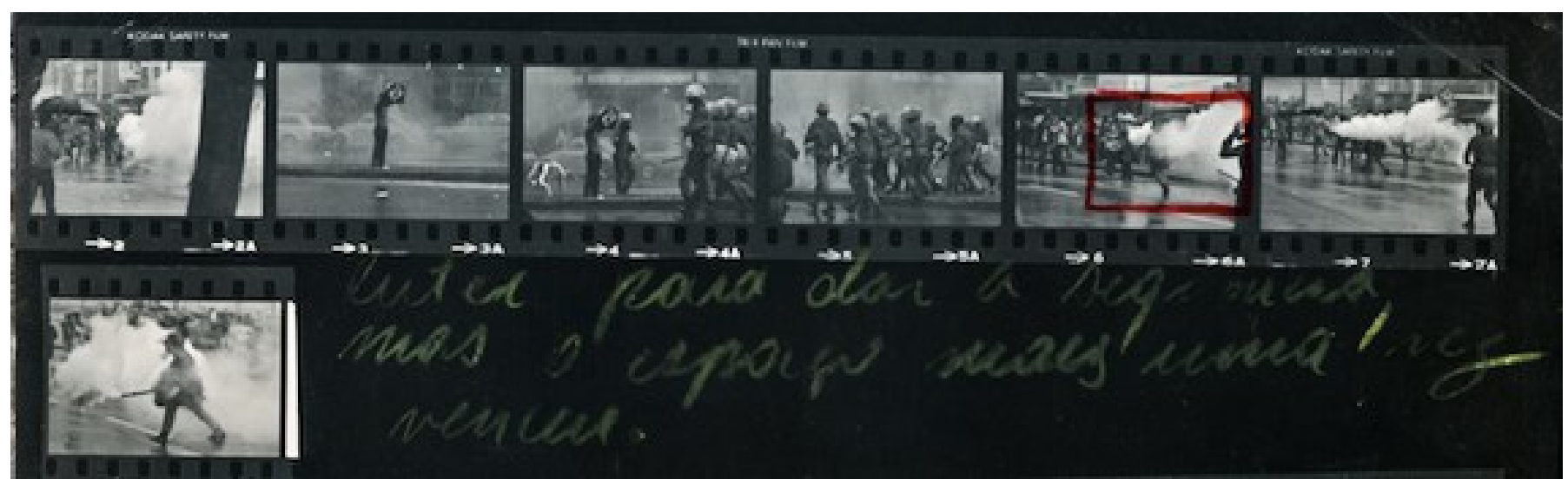

Figura 7: Folha de contatos de Ricardo Chaves, com o bilhete de Sergio Sade "Lutei para dar sequência, mas o espaço mais uma vez venceu".

Fonte: Acervo pessoal do fotógrafo.

Porém, uma segunda oportunidade surge para as imagens de Ricardo Chaves, quando a revista Veja realizou, em janeiro de 1978, uma retrospectiva do ano de 1977. Entraram novamente em pauta as manifestações estudantis quando a editoria de Veja afirmava: "Em todos os acontecimentos mais importantes de 1977, em suma, de algum modo se lembrou o compromisso de um retorno aos caminhos da democracia". ${ }^{43}$ Nessa edição, Veja publicou a sequência de imagens com a narrativa visual produzida por Chaves, deixada de fora da edição de 31 de agosto de 1977, devido ao espaço para o texto na fotorreportagem (Figura 8).

Os fotogramas $3,3^{A} ; 4,4^{A}$; e $6,6^{A}$ foram publicados na página inicial da edição, que fazia a retrospectiva das manifestações daquele ano (Figura 7), formando uma narrativa de cima para baixo na segunda página da fotorreportagem, apresentando ao leitor a menina que segurava a bandeira do Brasil na Av. João Pessoa, em Porto Alegre, no fotograma 3. A segunda foto (fotograma 4) dava a ver o avanço contínuo das tropas da Brigada Militar em direção ao local onde a manifestante se encontrava segurando a bandeira - em ato contra a repressão, pelo retorno da democracia e pela vontade do povo brasileiro representado pela bandeira nacional - e, por fim, a fotografia que já havia sido publicada em 1977.

43 Veja, 4 de janeiro de 1978. 

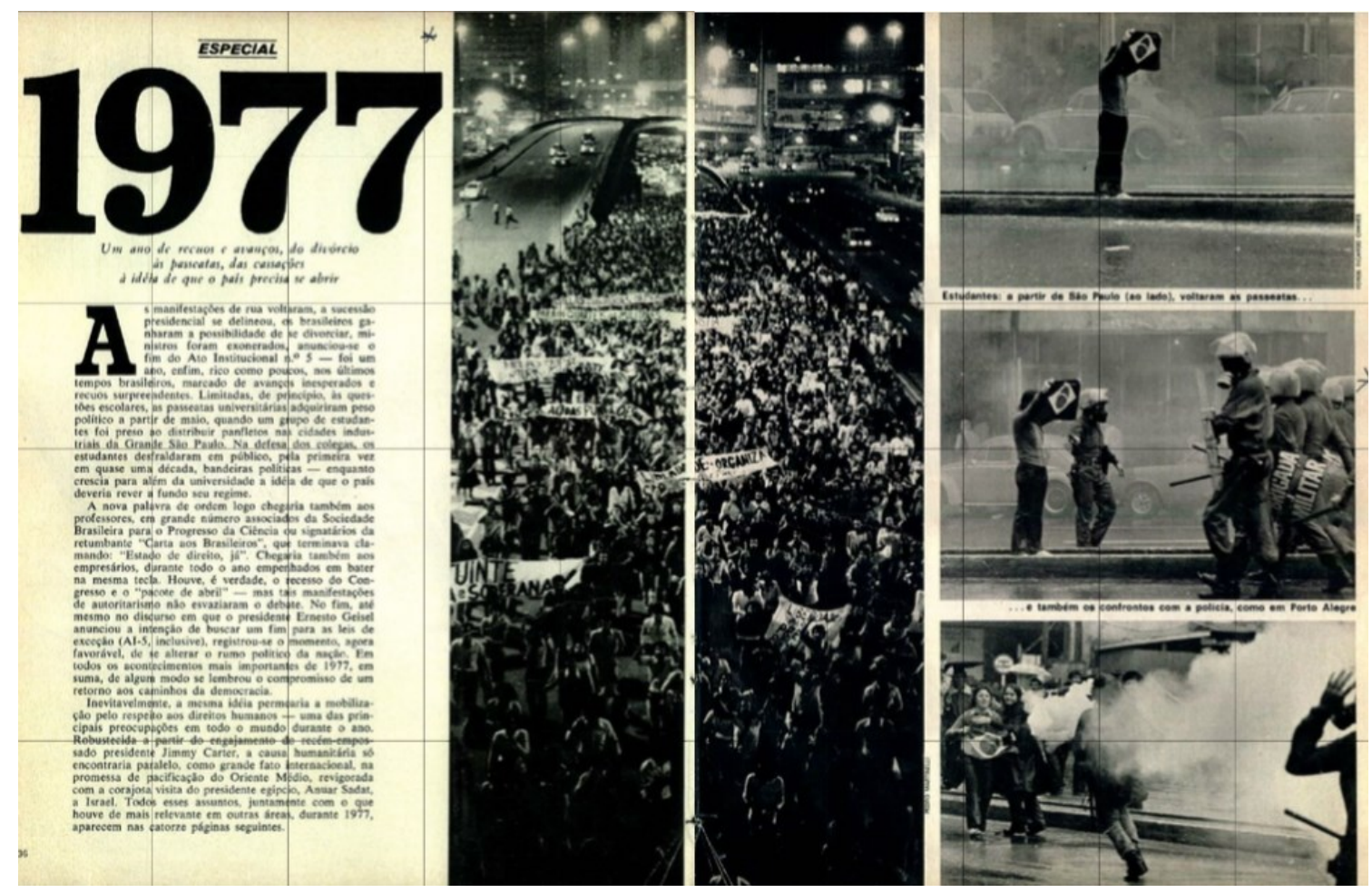

Figura 8: Fotografias de Ricardo Chaves publicadas na sequência em que Sergio Sade não havia conseguido publicar em 1977. Fonte: Veja, 4/01/1978.

Esse seria o momento em que Ricardo Chaves se desloca e se aproxima do local, fotografando o rosto da menina em prantos - em segundo plano -, enquanto a bomba de gás lacrimogêneo explode e os soldados da Brigada Militar continuam avançando - em primeiro plano. A sequência de fotografias de Chaves forma, ao lado da imagem de Pedro Martinelli das manifestações estudantis em São Paulo, um panorama sobre as manifestações estudantis em todo o Brasil publicadas em outras edições de Veja, ao longo de todo o ano de 1977.

\section{Considerações finais}

No momento atual da pesquisa podem-se fazer apenas algumas breves considerações sobre a visualidade construída pelas fotografias de Ricardo Chaves selecionadas pelo editor Sergio Sade e editadas na revista Veja, no ano de 1977. Houve uma ampliação na utilização da fotografia pela revista Veja na cobertura de temas como política, economia e sociedade. A revista produziu uma visualidade acerca das manifestações em prol da abertura política; cobriu e produziu diversas fotorreportagens sobre política e movimentos sociais brasileiros.

Por motivos do contexto interno da revista, a autocensura foi realizada em diversos âmbitos. Não havia espaço para o aprofundamento de opiniões divergentes entre jornalistas, editores de fotografia e fotógrafos pelo caráter empresarial de Veja, que visava resguardar seu 
futuro como revista em plena ditadura militar. Veja publicou, porém, fotorreportagens sobre temas polêmicos, como é o caso do sequestro da uruguaia Lilián Celiberti em Porto Alegre. ${ }^{44}$

A equipe de fotografia de Veja talvez não possuísse amplo controle sobre sua produção, porém o trabalho de Sergio Sade foi significativo no sentido de dar mais espaço e reconhecer o exercício autoral dos fotógrafos na produção das imagens. A implementação da editoria de fotografia foi uma tentativa de dar maior relevo à fotografia em Veja. Ela permitiu um espaço maior de diálogo entre fotógrafos e editores, o que não acontecia antes de 1977, quando quem decidia sobre quais fotos seriam publicadas eram os redatores da revista responsáveis pelo texto das fotorreportagens.

As imagens desses fotógrafos dialogavam e potencializavam os textos de jornalistas juntamente com o trabalho de edição de Sergio Sade. Veja publicou diversas narrativas visuais em formato de fotorreportagem e ensaio, contribuindo para colocar em um novo patamar o fotojornalismo brasileiro nos anos 1970. Esses fotógrafos, juntamente com uma grande equipe de profissionais da imagem, construíram e ajudaram a construir uma nova visualidade da sociedade brasileira e dos movimentos sociais. Para finalizar, cabe dizer que ainda é necessário pensar a relação de Veja com outras revistas de grande circulação nos anos 1970, bem como aprofundar a reflexão sobre as tensões e os conflitos na forma de produção do fotojornalismo nos grandes veículos de comunicação frente ao trabalho das novas agências de fotógrafos e cooperativas que surgiram no final dos anos 1970 com a bandeira da democratização da visualidade das camadas populares da sociedade brasileira.

Caio de Carvalho Proença: Mestrando em História pelo Programa de Pós-Graduação em História da PUC-RS. Realiza trabalho de investigação na linha de pesquisa Sociedade, Ciência e Arte, atuando no Laboratório de Pesquisa em História da Imagem e do Som.

Charles Monteiro: Doutor em História Social pela PUC-SP com pós-doutorado em História Social da Cultura (Universidade Paris 1 - Panthéon Sorbonne), professor adjunto de História no Programa de Pós-Graduação em História e coordenador do Laboratório de Pesquisa em História da Imagem e do Som da PUC-RS. Também é o coordenador nacional do GT Imagem, Cultura Visual e História da ANPUH.

\footnotetext{
${ }^{44}$ As reportagens referentes ao caso, abordadas no trabalho de conclusão de curso de PROENÇA, Caio de C. Fotojornalismo de Ricardo Chaves e Olívio Lamas em Veja: imagens do caso do sequestro clandestino dos uruguaios em Porto Alegre (1978-1980). In: Revista da Graduação da PUCRS, v. 8, n. 1, 2015, foram publicadas em Veja nos anos de 1978, 1979 e 1980. Em 1978: 28 de junho, 6 de dezembro, 13 de dezembro, 20 de dezembro e 27 de dezembro. Em 1979: 28 de março, 4 de abril, 16 de maio, 8 de agosto, 29 de agosto, 12 de dezembro e 26 de dezembro. Em 1980: 13 de fevereiro e 18 de junho.
} 